\title{
Is Cultural-Historical Activity Theory Threatened to Fall Short of its Own Principles and Possibilities as a Dialectical Social Science?
}

\section{Introduction}

In recent years, many researchers engaged in diverse areas and approaches of "culturalhistorical activity theory" (CHAT) ${ }^{2}$ realized an increasing international interest in Lev $\mathrm{S}$. Vygotsky's, A. N. Leont'ev's, and A. Luria's work and its continuations. Not so long ago, Yrjö Engeström (1993) noted that the activity approach was still "the best-held secret of academia" (p. 64) and highlighted the "impressive dimension of theorizing behind" it. Certainly, this remark reflects a time when CHAT was off the beaten tracks. But if this situation begins

1 The major part of this article is written by Ines Langemeyer. Wolff-Michael Roth contributed mainly to the outline of dialectics in Hegel's philosophy.

2 This term (and its abbreviation) has emerged a few years ago and tries to address simultaneously Vygotsky's "cultural-historical school" and Leont'ev's "activity theory" to emphasize the continuous elaboration of the theoretical basis. However, the thesis of a continuous development is still contested and also today approaches within this tradition have not been unified. In this article, we will refer to this neologism to name the diversity of approaches that relate to the work of Vygotsky and his collaborators. We will also use this abbreviation here, but more for convenience and without any allusion. to change today, in which direction will CHAT be heading? Will it continue to be one of those projects "unique for its practical, political, and civic engagement" committed "to ideals of social justice, equality, and social change" as it was in the beginning (Stetsenko \& Arievitch, 2004, p. 58)? Although a positive future of CHAT seems to lie ahead, we consider in this article some of the problematics that may challenge all those who want to pass the "impressive dimensions of theorizing" from "insider" circles to a larger audience and from one generation to another as well as encourage newcomers to become part of this tradition through critical engagement in its theory and practice. A key to these engagements, we suggest, is not only the comprehensive empirical and philosophical basis, but also the role of dialectics as both topic and method. Therefore, the challenge for newcomers (as well as for "old-timers") to take on the tradition of CHAT is not a small one indeed. We assume that a major reason for the increasing interest in CHAT lies in its potential to provide a non-reductionist approach to human development, which is due to its affinity to dialectics; 
however, the close interrelation to a tradition that reaches back to the theories of Georg W.F. Hegel and Karl Marx, among others, is not the easiest to master.

In consideration of these difficulties, the purpose of this article is to investigate how contemporary approaches within CHAT can continue to provide a dialectical framework to preserve and renew the critical intention of this tradition, and how we run the risk of losing this sting. Thereby, we sensitize researchers to the problem of developing a cultural-historical approach within a historical situation that confronts us with new, unanswered questions. In this light, we also problematize the use of scientific language, for it may lead us to speak and argue un-dialectically when in fact we intend or ought to think dialectically.

This article seeks to convey insights and arguments of how we can relate our theoretical approaches to a tradition of dialectical thinking and in what ways this is paramount for a critical engagement in theory and practice. In the first part, we therefore discuss not only some major theorems in Hegel's and Marx's work but also, and above all, Vygotsky's way of developing the cultural-historical approach of psychology. Second, we argue that the contemporary, widely known version of CHAT, related to Yrjö Engeström's theoretical and empirical work, neglects different aspects of dialectical thinking and consequently narrows its potential to a socio-critical approach to societal practice and human development. A crucial question of this scrutiny will be the notion of contradictions and how development is supposed to be achieved. In general, our intention is not only to clarify the role of dialectics as a method for activity theory but also to problematize the role of the subjects of research in CHAT and to confront ourselves with the problems of practicing and developing a critical science in face of a complex and challenging societal world.

\section{What are Perspectives of Dialectical Thinking? What are Dialectical Concepts?}

To realize the capacity of the dialectical approach, we first articulate how dialectical concepts were developed and how dialectical thinking proceeds. This philosophical background helps to understand CHAT's conceptual roots and highlight its potential for critical research. We begin by acknowledging that we cannot deny, as Wolfgang Fritz Haug argues, a fundamental problem of dialectical thinking is already inherent in each attempt to grasp the nature of dialectics: "It appears almost impossible to speak about dialectics without speaking un-dialectically, and thus, as the dialectician Brecht warned, to transform 'the flux of the things itself into a static thing' (6.1.48, Arbeitsjournal, Brecht 1993, 384)" (Haug, 1996/2005, p. 241).

In what follows, we do not claim (nor intend) to do justice to the entire history of dialectics. We merely seek to highlight in an exemplary way how and why dialectics are important in Hegel's and Marx's philosophies and why this has nurtured critical ways of theorizing. This provides a sufficient basis to explain how dialectical thinking has been at work in the development of Vygotsky's thought. Finally, after dealing with these sources of dialectical thinking, we summarize what characterizes different perspectives inherent in them in order to develop a more general idea of dialectics. ${ }^{3}$

\section{Dialectics as a (Self-)Critical Way of Thinking}

The first insight we can extract from Hegel is to grasp how and why he rejects a philosophical distinction of subject and object as separate

3 For readers who want to get a better orientation in view of this difficult matter, we suggest to begin with this section summary and then return to the following subchapters. 
entities in favor of the idea that both, in the realm of consciousness, mutually constitute each other. To this day, this radically questions those theories that take the independent existence of the subject of an epistemological or practical activity ${ }^{4}$ and its object for granted, as stable "elements," without any interest in their interrelations, their histories, and their changes in different contexts.

We begin with Hegel's reformulation of the problem of knowledge (of what we can know for sure or hold true) as a problem of the self: in so doing, he described a movement of thinking (consciousness) that stands for a powerful notion of dialectics in relation to German Idealism. To theorize this movement, Hegel starts with an undifferentiated subject of consciousness ("Geist," translated by some as "Spirit" by others as "Mind"). Consciousness, he argues, cannot remain subjective and as such identical with itself, because the notion implies an object of consciousness, for consciousness always is consciousness of something. This object of consciousness is other than the subject of consciousness, in fact, is the negation of the subject and thus unfolds a specific movement: "Spirit becomes object because it is just this movement of becoming an other to itself, i.e. becoming an object to itself, and of suspending this otherness" (Hegel, $1807 / 1977$, p. 21 [§36]). This becoming other to itself, negating and thereby alienating itself, allows consciousness to evolve when it "returns to itself from this alienation," because

4 In this sentence, the word "subject" indicates an individual or a group of people who act(s) intentionally on something in a certain way; by "object" we address that thing which is transformed by that action. Thus, we already interpret the subject-object-relation as a theorem that stands for the societal relation mediating between real human beings and their real social and natural environment. But in what follows on Hegel's philosophy, subject and object are merely poles or extremes within each movement of thinking. This difference is important to acknowledge before tranferring Hegel's dialectics to "real" phenomena. it is "only then revealed for the first time in its actuality and truth" (p. 21 [\$36]). Consequently, everything we know is a product of this movement of thinking (thought). This can be critically reflected upon only by making the movement available to another movement of thinking. Yet, the philosopher admits that "it is far harder to bring fixed thoughts into a fluid state than to do so with sensuous existence" (Hegel, 1977, p. 20 [§33]).

Connected to this problem is the question where this movement of thinking comes from and how it relates to our reality, which we seek to comprehend. Hegel's solution will become clearer as we explain the inner contradiction between subject and object. It may not satisfy us, however.

As mentioned, Hegel argues that subject and object are not independent entities but that they form a new unit. This new unit sublates ("hebt auf")—i.e., overcomes, includes, transcends, and destructs - the opposition between the two, which is articulated (following Johann G. Fichte and Friedrich W.J. Schelling) as activity. This activity stands for the idea that subject and object are mutually presupposing and constitutive opposites that cannot be thought independently and therefore are complementary but irreducible expressions of the same unit. But it is paramount that the unit does not result from a collation of the two-_"since object and subject, etc. signify what they are outside of their unity" (p. 23 [§39])_but rather, it sublates their difference. Hegel terms it "an inner difference"- - a difference of the thing with itself, which leads to inner contradictions of the unit. Thus, contradictions are included into the very nature of thought (cf. Tolman, 2001).

Such an inner contradiction now provides Hegel with a "mechanism" for movement which explains why contradictions can in fact make a unit: "The movement of a being that immediately is, consists partly in becoming an other than itself, and thus becoming its own 
immanent content; partly in taking back into itself this unfolding or this existence of it, i.e. in making itself into a moment, and simplifying itself into something determinate" (Hegel, 1977, p. 32 [\$53]). This self-movementbrought about by the inner difference-gives rise to self-differentiation, because consciousness, having turned a part of itself into the object, discovers contradictions. Consciousness resolves these contradictions by means of a process of sublation ("Aufhebung"), which both deconstructs and overcomes a contradiction in articulating new units of which the old contradictions are but moments and external expressions. Here, the term moment means that the units are identifiable structures in the new unit, but structures that cannot be thought independently from each other-they therefore are not elements. The movement, as Hegel assumed, could be observed not only in scientific thought but also in "common understanding [which], too, is a becoming, and, as this becoming, it is reasonableness" (p. 34 [§55]). This strong belief in an epistemological as well as societal process in which reason constantly progresses essentially characterizes Hegel's philosophy as he conveys that not only a conclusion ("Schluss," translated with regard to the philosophy of logic as "syllogism") would be rational, but everything rational would be a conclusion (cf. Science of Logic, Doctrine of the Notion, Subjectivity, ch. 3, \$1437).

Hegel's insights to the movement of thinking may lead us to a dialectical praxis of theorizing that challenges researchers not to congeal the object in their thoughts by identifying it with a single concept or by "fitting it into" a predetermined category, but "to allow the phenomenon to speak as such" (Adorno, 2005, Aph. 46). It is important to mention two major counter-arguments against Hegel's understanding of dialectics. First, the assumption of a historical progress by which society would become increasingly rational and reasonable has been criticized as a hope of Enlightenment that has to be rethought especially in view of the appalling dialectics of "instrumental reason" in the $20^{\text {th }}$ century. ${ }^{5}$ Second, it has often been argued against Hegel that the bridge to overcome the difference between reality and thinking still remained wishful thinking. Let us therefore take a look at Marx's understanding and use of dialectics that also has been one important background for the mentioned counter-arguments against Hegel.

Marx acknowledges Hegel's method and his idea to comprehend "every form in the flux of movement" (MECW 35, p. 20). However, he also develops a fundamental critique of it and rejects it for its "mystified form" (MECW 43, p. 31; cf. MECW 42, p. 544 and 40, p. 249). For Marx, the problem is that "Hegel fell into the illusion of conceiving the real as the product of thought concentrating itself, probing its own depths, and unfolding itself out of itself, by itself” (Marx, 1973, p. 101) and that

"empirical actuality is admitted just as it is and is also said to be rational; but not rational because of its own reason, but because the empirical fact in its empirical existence has a significance which is other than it itself. The fact, which is the starting point, is not conceived to be such but rather to be the mystical result. The actual becomes phenomenon, but the Idea has no other content than this phenomenon. Moreover, the idea has no other than the logical aim, namely, 'to become explicit as infinite actual mind'.” (Marx, MECW 3, part 1)

Marx warns us not to overestimate the power of Hegel's method, because in so doing, dialectics could be misinterpreted as a universal law (as Engels did later, for example, cf. MECW 24, p. 301). In contrast to this, Marx seeks to transfer and employ it in a "critical and revolutionary" way (MECW 35, p. 20).

5 Cf. Horkheimer/Adorno (1947/2002): Dialectics of Enlightenment; cf. Adorno (1955/2005): "Dialectical reason [Vernunft: reason] is, against the ruling one, unreason [Unvernunft]: only by carrying over and sublating the latter, does it become rational [vernünftig: reasonable, rational]" (Aph. 55). 
We clarify how this contributed to a self-critical way of thinking in this next step of our brief outline of dialectical thinking.

An important dimension of Marx's critical use of dialectics can be traced to his First Thesis on Feuerbach. Here, Marx develops one of his three major critiques (Haug, 2001), ${ }^{6}$ the critique of the "form of the object" within the non-dialectical and a-historical epistemic activity ("Erkenntnistätigkeit"):

The chief defect of all hitherto existing materialism (including that of Feuerbach) is that the object ["Gegenstand"], reality, sensuousness, is taken only in the form of the object ["Objekt"] or of contemplation, but not as sensuous human activity, praxis, not subjectively. Hence, in contradistinction to materialism, idealism developed its active aspect, but only in abstract form, because, of course, it does not know real, sensuous activity as such. (Marx, 1969, p. 533)

As Haug (2001, pp. 92-94) explains, this critique makes a simple but revolutionary turn by posing the question of how reality comes into the form of the object. Like Hegel, Marx presupposes here the complementary unity of subject and object, but instead of searching for their progressive mutual relationship in a rational historical process that is allegedly reflected in the movement of thinking, he acknowledges the difference between the epistemic and the real object and detects an ideological effect of any purely epistemic activity relating subject and object: Within this movement of thinking, Marx conveys, reality would no longer appear in the form of objects of practice. It remains passive contemplation that disregards sensuous

6 Haug (2001, pp. 92-93) argues that three critiques are developed in Marx's work beginning with the critique of the form of the object, which we explain here; second the theory of ideology, which goes far beyond the critique of false consciousness for it investigates ideology as a function of domination and regulation; and third, the analysis of the form of value starting with use and exchange value and reaching to the inquiry of the complex forms of capital. activity - and with it its societal basis and its natural resources.

Against this ideological effect, dialectics become salient in Marx's own theorizing to reconstruct reality from the standpoint of praxis and, in doing so, to study "the connection of that which at first appears to be without connection, the connection at the point of origin of the phenomena which appear as disparate in the result" (Haug, 2005, p. 246; original emphasis eliminated). To avoid the "speculative dialectics" of Hegel, Marx emphasizes that in each case the limits of dialectics need to be determined and that the difference between the real object and the epistemic object, between reality and thinking, should not be neutralized (Marx, 1857/1973; MEW 42, p. 43). This may clarify why Marx claimed that his version of dialectics is "not only different from the Hegelian, but is its direct opposite" (MECW 35, p. 19).

\section{Building on Dialectical Theorizing}

The way towards a cultural-historical approach to human development in Vygotsky's work exemplifies how dialectical thinking became both an inherent topic of theorizing as well as a method to overcome the limits of given theoretical insights about consciousness. From its very beginning Vygotsky's collaborative project rejects (a) any dualism between physiological and mental phenomena (and accordingly between their materialistic/objective and idealistic/subjective explanations) and (b) any dichotomy of the individual and the society of which the individual is a constitutive part. Consequently, dialectics is used for detecting (a) the connections between physiological and psychic phenomena and (b) the individual and societal dimensions that were considered the result of their co-evolution.

But this insight did not come from a sudden revelation or discovery of dialectics. Dialectical thinking can be seen already in the early works of Vygotsky when he started to elaborate his own approach as a young researcher in 
the Institute of Psychology (Moscow). At that time, he was concerned with the shortcomings of Pavlov's reflexology and its physiological concepts that neglected human consciousness. Nevertheless, Vygotsky applied the concept of reflexes to mental processes and aimed at developing a wider notion of behavior by making consciousness an integral part of it. Thus, he still followed the principle of an "objective psychology," but by transferring it to the domain of consciousness, he imbued the concepts with inner contradictions and finally disrupted the framework of reflex theory. (Silvonen [2005] therefore applies Althusser's notion of an "epistemologic break" to Vygotsky's theoretical development.)

Influenced by Gestalt- and Ganzheits-psychology, Vygotsky criticized the behaviorist associationism for explaining developmental processes on the basis of isolated elements. Although he sympathized with the integral or holistic approach of psychologists like Kurt Koffka, Wolfgang Köhler, or Kurt Lewin, he found that their analysis lacked a genetic or socio-historic understanding of psychological phenomena. Vygotsky started to rethink psychological methods according to dialectical thinking. Following Darwin's and Marx's historico-genetic insight that "the anatomy of man is the key to the anatomy of the ape," he postulated transferring "basic categories and concepts from the higher to the lower" level only (Vygotsky, 1927/1987, CW 3, p. 235). But this method was exactly rejected in Pavlov's theory that applied a physiological concept ("reflex") observed in animal behavior to human psychology.

From the historico-genetic perspective, Vygotsky built on the dialectical insight that "the elaboration of concepts, methods, and theories takes place within the science itself during the whole course of scientific knowledge acquisition, i.e., the transition from one pole to the other, from fact to concept, is accomplished without pausing for a single minute" (p. 253).
Vygotsky recognized that each reality as an object of investigation as well as each scientific theory and methodology must be conceived as a historical product of human labor. Thus, "a theory of method is, of course, the production of means of production" (p. 253). For his own psychological approach he emphasized:

We wish to obtain a clear idea of the essence of
individual and social psychology as two aspects
of a single science, and of their historical fate, not
through abstract considerations, but by means of an
analysis of scientific reality. [...] The methodologi-
cal investigation utilizes the historical examination
of the concrete forms of the sciences and the theo-
retical analysis of these forms in order to obtain
generalized, verified principles that are suitable for
guidance. (p. 237) Accordingly, Vygotsky (1978) came to postulate that psychological matters should be studied "in the process of change," in its "development of all its phases and changes" (p. 64-65) to fulfill the demands of a dialectical method. More precisely human development was interpreted as a process of enculturation and humanization, in which biological and cultural lines of development were interrelated through a co-evolution of the societal basis as an "environment," on the one hand, and the individual development in different forms of social agency and activity, on the other hand.

To take the various mediations of this development into account, Vygotsky (1934/1987) introduced the notion of a "unit" for the analysis of human behavior. He argued that such a unit has to be the smallest "part" of the whole, which nevertheless embodies the whole and therefore does not reduce the complexity of the research objects in process.

In our view, an entirely different form of analysis is fundamental to further development of theories of thinking and speech. This form of analysis relies on the partitioning of the complex whole into units. In contrast to the term "element", the term "unit" designates a product of analysis that possesses all the basic characteristics of the whole. The unit is 
a vital and irreducible part of the whole. [...] In precisely the same sense, the living cell is the real unit of biological analysis because it preserves the basic characteristics of life that are inherent in the living organism. A psychology concerned with the study of the complex whole must comprehend this. It must replace the method of decomposing the whole into its elements with that of partitioning the whole into its units. Psychology must identify those units in which the characteristics of the whole are present, even though they may be manifested in altered form. Using this mode of analysis, it must attempt to resolve the concrete problems that face us. (pp. 46-47)

Vygotsky suggested that the notion of "word meaning" (as well as "emotional experience" [perezhivanie], Vygotsky, 1934/1998, p. 294; cf. van der Veer, 2001, p. 101) would enable such a unit analysis, because it is not only " $a$ unity of thinking and speech" but also "a unity of generalization and social interaction, a unity of thinking and communication" (1934/1987, p. 49), and thus, it would not "divorce the communicative function of speech from its intellectual function" (p. 48).

On the basis of this unit analysis, $\mathrm{Vy}$ gotsky's approach provides an understanding of the development of higher psychic functions and their "the genetic roots" (p. 51) that no longer sees them in isolation, only to be added or associated to one another in different stages; instead, each psychological function is comprehensible only when we see it as a part of an interfunctional structure which ontogenetically co-evolves within a certain sociocultural environment. Feeling and thinking, for example, could not be understood when they are investigated as separated phenomena detached from a person's social life.

There exists a dynamic meaningful system that constitutes a unity of affective and intellectual processes. Every idea contains some remnant of the individual's affective relationship to that aspect of reality which it represents. In this way, analysis into units makes it possible to see the relationship between the individual's needs or inclinations and his thinking. It also allows us to see the opposite relationship, the relationship that links his thoughts to the dynamics of behavior, to the concrete activity of the personality. (Vygotsky, 1934/1987, pp. 50-51)

Vygotsky excavates three dimensions of mediation taking place - the use of sign, the use of tools, and social interaction or cooperation. Therefore, the late Vygotskian approach can be acknowledged as a theoretical perspective that comprises all these different forms of mediation in relation with each other (Silvonen, 2005), thus providing a dialectical method to comprehend matters of research in its movements, transitions, interactions, conflicts and contradictions. Yet, although Vygotsky (1927/1987) believed that "the laws of thinking and the laws of nature correspond necessarily with each other as soon as they are known properly" (p. 256; see also Engels, 1925/1978, p. 493), he also recognized the socio-historical limits of theorizing, because "when the material [of scientific investigation] is carried to the highest degree of generalization possible in [one] science, further generalization is possible only beyond the boundaries of the given science and by comparing it with the material of a number of adjacent sciences" (Vygotsky, 1927/1987, p. 254).

\section{Section Summary}

Within the development of Vygotsky's work, we conceive a practice of theorizing through the lenses of Hegel and Marx, but which nevertheless shows its own history of transferring and transforming these approaches in view of specific objects of study ("Forschungsgegenstände") and its determinations through scientific research. Most salient about Vygotsky's dialectical thinking is that it radically takes into account that human practice as social interaction, collaboration, and human development cannot be adequately theorized if it is reduced to a self-reliant, thing-like "object". It is a socio-historical, shifting, and multi-di- 
mensional object of study ("Gegenstand") that cannot be investigated by looking at isolated elements or components but by determining relevant "units" of it only.

To extract a more general idea of the previous discussion, we argue that several dimensions of dialectics are important in order to understand and recognize the potential of CHAT's theorizing of human practice and development, as it builds on the following principles of dialectical thinking:

- study a phenomenon in its most developed form as a way toward explaining its previous forms (historico-genetic perspective);

- study the whole instead of isolated parts or elements to preserve the inner relations between the parts of a whole (holistic perspective);

- reduce the complexity of the objects of investigation without reducing them to false abstractions (structuralist, integral, or organic perspective);

- study a phenomenon in the process of change (perspective on dynamics, mediations and transformations); and

- reflect the process of theorizing and determine the (historical) limits of scientific concepts, insights and generalizations (self-critical perspective).

These perspectives, of course, do not guarantee a socio-critical theory, but they help to understand a practice-based co-evolution between the natural and the social or between the social and the individual lines of development (instead of their dualistic comprehension), and to conceive such objects of study as something constituted and changed by societal relations instead of a constantly remaining and stable thing. Everything needs to be seen both as determining and determined within its relation to other things but the scope and the scale of their impact can differ. Accordingly, in research activities, also the objects of study need to be reflected as products of societal forms of perception, thought, and practice and therefore, scientific investigation may lead to discover possibilities to intervene.

But dialectics precisely does not (and should not) serve here as an "instrument" to overcome the shortfalls of traditional forms of investigation. This would imply a misunderstanding, namely to look for dialectics merely as a method. We should not expect it to be something that could simply be "applied" to research matters like a standardized procedure or even a tool. Instead, dialectical thinking becomes a challenge to constantly question a variety of presuppositions concerning research practices: why and how something should be investigated and how this precipitates certain scientific representations of reality, which interrelations can be recognized as essential and how their genesis can be explained, who gets involved in a research project and who is not, what are the means and methods of inquiry, where do they come from, and what role(s) are they playing in the research process (cf. Nissen \& Langemeyer, 2005). This questioning is paramount when a critical approach is elaborated and when scientific thinking is developed as a practice of emancipatory intervention.

\section{How can Dialectical Notions be Misunderstood in a Functionalistic and Systemic Way?}

It is in this spirit of CHAT as dialectical science that we also raise fundamental questions concerning our own subject position as researchers within a certain research field - what roles we are playing in it and how we deal with the presuppositions of our own research activities_-which has become a tightrope walk for probably every researcher nowadays, since increasingly, the conditions and the guidelines for research are predetermined by institutions 
or enterprises that finance projects, how they select applications, or accredit research activities and their outcomes. Therefore, the main intent of problematizing the use of concepts and visual representations in Engeström's publications is not so much to show a lack of quality, because his texts consistently develop their argumentation and often corroborate it with wide empirical research; rather, we want to make those researchers attracted to this version of CHAT aware of several fundamental problems in it-related to a misinterpretation of dialectical concepts - that tend to impair critical engagement in the contemporary academe and today's research fields. Thus, we discuss the ways CHAT needs further elaboration to meet these challenges so that it continues to develop.

Following the self-critical perspective, our analysis questions the notion of activity as it is represented and interpreted by a triangular model to discuss its impingement on guiding and interpreting empirical research. According to the holistic perspective, we examine how subject, object, and their relationship are theorized by Engeström as "units" and in what ways they tend to be reified as isolated elements. With regard to the historical development of societal practice, we explore why Engeström's notion of activity (and its triangular representation) proves rather indifferent about the broader societal relations that determine practice and by which human activities develop historically. Connected to this, we discuss why a genetic reconstruction of specific human activities including the examination of their dynamics and transformations is quite difficult by means of an "activity system" that tends to blur the distinction between the individual and the societal level. From the structuralist perspective, we investigate the capacity of the triangular model to grasp essential interrelations of human activity and how these interrelations are considered. But first of all, we begin with a brief outline of Engeström's own commitment to dialectical thinking to determine what his theory aims at.

\section{Some Problematic Implications of "Activity Systems" and their Triangular Representation}

In a general reflection on human activity, Engeström acknowledges the importance of dialectics, or more precisely, of dialectical concepts because "[c]ontrary to the common notions, dialectics does not see 'concrete' as something sensually palpable and 'abstract' as something conceptual or mentally constructed. 'Concrete' is rather the holistic quality of systemic interconnectedness" (Engeström, 1987, ch. 4). While searching for systemic interrelations inherent to human activity and its holistic notion, Engeström defines "the task of genuine concept formation" as to find out "the developmental 'germ cell', the initial genetic abstraction, of the totality under investigation" and "to develop it into its full concrete diversity." Herein would lie "the kernel of the "other logic' Vygotsky pleaded for but could never formulate" (1987, ch. 4). To compensate this lack, Engeström determines and depicts the "activity system" as a triangular model:

The lineage from Hegel to Marx and Engels, and further to Ilyenkov and Davydov [...] suggests that the models needed here are of the germ cell type, expressing the genetically original inner contradiction of the system under scrutiny. Such models function not just as devices for diagnosing the behavioral state of the given closed system but as means for tracing and projecting the genesis and expansive transitions, or 'fluctuations,' of an open system. I suggest that the triangle models of activity [...] may be considered as an attempt at such modelling. (Ch. 4) 


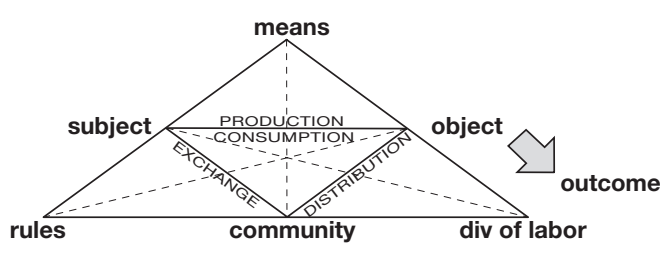

Figure 1. The "triangle of activity," has become emblematic for cultural-historical activity theory.

In Developmental Work Research, this triangle is presented as the extension of Vygotsky's model for a psychological mediation, ${ }^{7}$ enlarged by three triangles at the bottom to represent an activity as the new unit of analysis (Engeström, 2005, p. 60). This unit now contains, besides the subject, object, and the mediating artifact in the upper triangle, the mediating conditions of an activity indicated at the bottom: the division of labor, community, and rules. Thus, an activity system is supposed to represent collective forms of practice and should allow not only grasping the entire structure of an activity, but also the history of practices, its changes and developments. This "history may become manageable" if "a collective activity system is taken as the unit" of analysis" (p. 25). In the context of workplace learning, Engeström suggests including even two interacting activity systems in the "unit of analysis" to understand, beyond individual learning, collective learning processes by which societal practices (activities) are developed and transformed across the boundaries of activity systems (p. 62).

Engeström problematizes that "the concept and structure of activity are treated as if something rather self-explanatory" (p. 25)

7 In fact, Vygotsky did not invent the triangle to model a mediated act as Engeström interprets it. He only used the triangle to contradict the associationism of Pavlov's reflexology that depicted learning as an immediate conditioning of a stimulus to a reflex. The mediation did not refer to the relation between subject and object, but still to the one between stimulus and response. and proposes, that in order "to take full advantage of the concept of activity in concrete research," it would be necessary "to create and test models which explicate the components and internal relations of an activity systems" (p. 29). If this demand includes the triangular model of an activity system, we can acknowledge that Engeström's approach is consistent with what has been exposed in the last section as the perspectives of dialectical thinking. He agrees with the general objective of activity theory to overcome dichotomies between the individual and cultural or societal nature of activity (p. 20), between object-related activity and communication (p. 32), and thereby surmount "the individualist and ahistorical biases inherent in theories of action" (p. 22). Engeström also aims at taking account of the real practices not as "fully predictable, rational and "machine-like"" actions, but rather as processes that "involve failures, disruptions and unexpected innovations" (p. 32), and seeks to "illuminate the underlying contradictions which give rise to those failures and innovations as if 'behind the backs' of the conscious actors" (p. 32). In addition, he considers the activity system to be "a multi-voiced formation" in which "the different voices" are "layers in a pool of complementary competencies" (p. 35).

Each theoretical explanation about the triangular depiction of an activity system may be connected to a convincing argument; however, in sum, they seem to be questionable and rather unclear: Since the model is supposed to represent the entire activity, it evokes the questions about how it can simultaneously represent a "germ cell" and reduce the complexity of the whole in a "manageable way" when we investigate work place structures and theorize their implications for human development (cf. Langemeyer, 2005a). And if the triangular model is to guide us here, does it really provide a holistic perspective on the basis of an activity system or does it turn to an unfortunate 
encounter with a systemic totality? In other words, does the model really register those interrelations that render an activity system into an irreducible and undividable whole or does it suggest completeness by means of a systemic figure only? In the latter case, we would run the risk of losing the social and societal complexity of human practice, before we have been able to recognize it.

This leads us to question more concretely how the single triangle can help to comprehend any change or movement within the activity represented except in its outcome. It is invisible, for example, how the subject transforms the object of activity and how it simultaneously appropriates its own nature, its body, and how it develops its potentials and capacities. The representation appears to suggest that the subject's motives and intentions to become engaged in a certain activity would be identical with its outcome(s). It therefore reminds us of an instrumentalist concept of action that focuses-like Max Weber-on the rationality of means and ends. Furthermore, one can get the impression that (a) the constituents of this system (subject, object, tool, community, rules, and division of labor) are mutually determining each other, (b) these determinations are essential for every component, and (c) as long as the activity is going on, these components remain the same. Otherwise we would have to conclude that the model does not capture an irreducible and holistic unit of the essential inner structure of human practice. But because it simultaneously tries to recognize the entire complexity of any activity in general, we ask whether this model leads researchers to find its constituents, before looking for its specific relationships, interdependencies, determinations, and changes in practice. This would imply seeing them, first of all, as self-reliant elements. In other words, is there a danger that a researcher is led to start from a perspective that s/he immediately has to repel, if s/he tries to reinvent the perspectives of dialectical thinking in her/his research activity?

We acknowledge that models always exclude some aspects and interrelations to highlight others. But if we follow the subject-object-axis, the triangular model favors a third-person perspective, rather than a subjective or an intersubjective view. This inherently implies that the logic of the system is that of the analyst, the "neutral observer," rather than that of the participant. ${ }^{8}$ Otherwise it could be important for example to represent the reasons for acting ("Handlungsbegründungen") and the perceived possibilities for acting ("Handlungsmöglichkeiten") of those who are involved in a certain practice. In work relations, for example, the possibilities to assign a task to somebody, to take on a certain responsibility, or to refuse it are in general very different for employees. Since the participants' power, influence, competence, and interests vary, their subjective reasons to get engaged in a certain activity and the ways in which they act are heterogeneous. If we identify every employee with the "subject" in the model, we would favor a homogeneous subject position and neglect the differences in subjective reasons to act and consequently heterogeneous ways of acting, too. But if the triangle may be read as representing our, the analysts' perspective, it does not depict our position in or our relation to the activity system either.

We admit that up to now, these critical questions have been directed at the triangular model only. But can we also detect such ambiguities and lacks of clarity in other texts that theorize and deal with empirical data?

\footnotetext{
8 It is irrelevant for this argument that in several research projects, participants also use the model to come to a better understanding of their own work practice, for example. We do not deny that the triangular model could be an opportunity to reflect and discuss different perspectives of those who are involved. However, such an appropriation of the model does not refer to what it actually visualizes.
} 


\section{Reading exemplary cases of theorizing and research practice}

First case: Let us take an example from Developmental Work Research (Engeström, 2005). To clarify the inseparable unity of activity and communication, a work situation described by Hart-Landberg and Reder (1997, p. 365) from a manufacturing plant is presented:

The Rexford, a machine for grinding metal bars into components for automobile accessories, "crashed." Teresa was just concluding her first week operating it. Team members milled around, trying to figure out the cause of the crash. To anyone who was listening, Teresa expressed her guilty feelings: "It had to have something to do with the operator." Jeff disagreed. "The same thing has happened to all of us." Then he warned her that the tooling experts assigned to troubleshoot this problem probably would tease her as they teased all operators involved in such breakdowns. Immediately an expert arrived and took Teresa aside to talk to her. Later another young machinist of the team, Carrie, told the observing author that the problem of Teresa's machine had not been her fault: It was the machine's. "Some of the best machinists come out from a situation where the machine crashes all the time," Carrie maintained.

In the aftermath of the breakdown, an item on the team meeting agenda was: "Update on the Rexford." Chuck, the team's oldest worker, with years of experience operating and fixing the machine, recounted that after the crash he had "rebuilt," "remade," "realigned," and "recentered" all the Rexford parts which had been "wiped out really bad," "burnt up," "shoved back," and "had gullies in them." After participants stopped chuckling at the extent of Chuck's chores, he asserted, "It's not Teresa's fault." But Teresa still seemed worried about her culpability: "It was only the second time I've loaded bars... but Emily loaded a similar bar [with no resulting breakdown]."

Participants then launched into a technical analysis of a bar size and developed a new recording procedure for tracking undersize bars to prevent future breakdowns. Thus the team's response to the breakdown was to support Teresa and attempt to improve the production process by creating a new type of written record. (Quoted in Engeström, 2005, p. 139)

Engeström presents this example as a "nice illustration" for how "organization emerges in the interplay between conversation and text," namely through "a new type of written record as a response to the breakdown" (p. 139). The text is used to problematize conversation and critical discourse analysis for neglecting the "continuous change and developmental struggle" (p. 141) and to criticize the " distance' between practical activity and discourse" (p. 144) as well as the lack of "an explicit interest in and analysis of radical transformations" (p. 155). Although this critique may be adequate and striking, we shall read the way in which Engeström proceeds to argue in a symptomal way: we shall look for aspects, questions, and explanations that are left out and assumptions that are not further explicated for they seem to be evident. In other words, we want to pay attention to issues that Engeström leaves unproblematic.

Most significant in the introduction seems to be the fact, that we, as readers, are not informed about how the authors of the quoted passage were engaged in their "ethnographic study of teamwork and literacy" (p. 139). We are not provided with an explanation about what the original authors were doing in their research project and why. Neither do we know who really observed and reported this situation, what has been selected to present and what has been ignored. Therefore, the purpose and status of this original text remains rather unreflected. Neglecting all this presupposes something like an unproblematic third-person's perspective. Thus, it becomes significant that another text is quoted and interpreted as if it were a neutral record of a situation that only "looks for" a scientific analysis. Because Engeström does not problematize it as a theoretically biased perception and product of research activity, he also omits other plausible ways of interpreting the 
object of study that would be contrary to his conclusion.

Engeström suggests that "the conversational events [...] may be interpreted as attempts to influence the recipient's beliefs and actions" as for example: "The team members reassured Teresa, and the tooling expert assumedly teased Teresa making her feel guilty" which could be a sign for "competing ways of enacting organizational power structures by asserting authority over an individual worker" (p. 140). Engeström argues that this conclusion would be insufficient, if we do not relate it to the fact that "the crucial outcome is a new production procedure for tracking the bars" (p. 140). And instead of reducing organizations "to small fragments of discourse," we would have to acknowledge that they "carry histories" (p. 142). However, in the Rexford case, Engeström does not present additional information about the histories of that specific work procedure and the workers' relationships or the management and the organization that characterize their work places as well as their forms of collaboration within the company. He suggests that the "whole incident [that Teresa showed self-criticism] may be interpreted as a fairly complex systematic disturbance in the activity, rather than just another demonstration of power relations" (p. 147). But what is the evidence for this thesis? To corroborate it, Engeström invokes the triangular model and reinterprets the moment and the aftermath of the breakdown of the machine as a "disturbance" of an activity system.

A first figure shows "Teresa's doubts and confusion regarding her own possible contribution to the disturbance" as well as "reassurance and support from team members to Teresa" (p. 147-148). Another figure visualizes the "conversation between Teresa and the tooling expert" to find out "with what intellectual tools might one diagnose and repair the crash" (p. 148). A third figure represents the activity of Chuck telling a story about the repairing and the "outcome being a closure on the repair of the machine" (p. 149). A fourth figure depicts the "development of the new recording procedure in the team meeting" (p. 149).

It is surprising that these figures represent certain ways of being of a singular person and others show at best their individual actions, but illustrated as activities. This is confusing with regard to Leont'ev's distinction between action and activity where the latter is the collective, cultural-historically developed practice of humans to achieve a certain form of need satisfaction and the former is a contribution to this collaboration. Since the triangular model seems to be applicable to intra- and interpersonal activities (like inner speech, communication, and collaborative activities) as well as societal practices (like an entire production process) and tends to identify a personal motive with the outcome(s) of an activity, it seems to ignore essential differences between the societal, the intra- and the interpersonal plane of human practice. This would surely impair a historico-genetic perspective on how specific activities develop and change under certain, more general, societal conditions. ${ }^{9}$ Furthermore, our assumption or fear that subjects, objects, tools and so on are "assembled" as isolated elements can also be affirmed for neither Teresa nor Chuck appear as subjects who are situated in the given collaboration due to their subjective vital interests (Lebensinteressen), to a certain mode of participation and to the ways of being recognized by others (cf. Dreier, 1999; Holzkamp, 1993). ${ }^{10}$ Instead, the figures represent them as

9 An example for this would be the investigation of different work processes that get reshaped through the implementation of information and communication technologies.

10 Erik Axel and Morten Nissen (1993) have already discussed in what ways work the distinction between the individual and the societal level of activity is blurred 
actors without subjective reasons to act, separated from their own interpretive horizons, biographies, and social positions or status (as gender, age or competence/qualification, for example). We do not know, for example, what it really means for Teresa to experience the breakdown of the machine while operating it. Is she afraid of sanctions or of being disregarded as an unqualified woman, for example? Nor can we really interpret the motives for the support coming from other team members. This could be a fair manner to deal with problems at work, but it could also be a strategy to ensure the competitiveness of the team according to what currently is investigated as new economized organization structures and forms of "lean management." In such a case, we might expect that beneath the support remains a quite painful pressure to perform. Such a plausible scenario could explain why Teresa keeps worrying about her own contribution to the breakdown despite getting support from different angles. Yet, this conclusion would need more empirical data and a thorough investigation that would also require a dialectical analysis of that praxis, especially in face of a co-existence of cooperation and competition.

By showing some alternative ways of inquiry and interpretation, here, we seek to clarify that the triangular representations of

in Leont'ev's work and which problems are connected to this: "Paradoxically, [...] the attempt to unify social and individual activity by the category of motive opens the road to separate options: Determining activity by its motive, we are caught oscillating between the two poles in a dichotomy in the theoretical functions of the concept of motive. At one pole, motives depict how the individual merges into societal activity; at the other, they depict how the individual regulates her individual and not necessarily societal activity. Furthermore, defining an activity by its motive paves the way for subjective arbitrariness in research. Deciding whether an object of investigation is an activity or an action is a matter of what sort of motive configuration the researcher sees or reads into the individual under investigation.” (p.71) the supposedly activity "systems" neglect the ambivalent and contradictory nature of such relationships and the entire situatedness of the subjects involved. This indicates that the subjects, tools, and objects and so on are treated as "constituents" or "elements," and tend to be reified with all the other "elements" of an activity to fit into a system structure, because each of them is divorced from several culturalhistorical dimensions and social-individual meanings that vividly bring about and influence societal praxis.

Certainly, this focus on systemic structures corresponds to what the analysis seeks to reveal as "invisible' disruptions and creative efforts in activity and communication" to make "visible the scripts and boundaries of "normal operation"” (Engeström, 2005, p. 152). This implies_-actually quite similar to conversation analysis - that individual perspectives are only of interest in so far as they explain something of these scripts and boundaries. Engeström suggests that there is a striving inherent in activity to overcome boundaries by creating new scripts, operations, communications, and procedures but we do not find sufficient reflections on this striving as a personal motive/motivation for change.

Furthermore, Engeström's argument against conversation and discourse analysis that, "while power and domination are at work in contradictions, it is important to distinguish contradictions from a general assertion of asymmetric power relations" (p. 152). However, we may doubt that a full understanding is achieved in the presented framework concerning the scale of how power relations affect practices through their impact on human relationships and subjectivities. To investigate these shortcomings, we draw on another case study, published and conducted by the same author.

Second case: In what follows, we discuss a project carried out in 1998 and published 
with the title "Expansive Learning at Work: Toward an Activity Theoretical Reconceptualization" (Engeström, 2001; republished in 2005). It took place in the area of children's health care in Helsinki and sought to improve the collaboration between two different institutions. The report presents it as an exemplary case for a real developmental process achieved through "expansive learning at work." Such a collaborative learning process maintained by these institutions would have been necessary, because "the issue at stake was organisational, not resolvable by a sum total of separate individuals" (Engeström, 2001, p. 140):

A critical structural issue in the Helsinki area is the excessive use of high-end hospital services, historically caused by a concentration of hospitals in this area. In children's medical care, the high-end of medicine is represented by the Children's Hospital which has a reputation of monopolizing its patients and not actively encouraging them to use primary care health centre services. Due to rising costs, there is now much political pressure to change this division of labour in favour of increased use of primary care services. The problem is most acute among children with long-term illnesses, especially those with multiple or unclear diagnoses. [...] Such children often drift between caregiver organizations without anyone having overview and overall responsibilities of the child's care trajectory. This puts a heavy burden on the families and on the society. (p. 139)

Given that political pressure was exercised on the hospital and services indicates that, already from the beginning, the problem of the collective learning process was more or less defined. Only the way of improvement was practically unresolved. Thus, the idea to change something came from the outside, from a higher political level. However, the employees in the health care system and the families were determined to be the subjects of learning. Engeström reports: “The Children's Hospital decided to respond to the pressures by initiating and hosting a collaborative redesign effort, facilitated by our research group using a method called Boundary Crossing Laboratory" (p. 139). But what we do not know is whether this decision was supported by everyone in this context or whether there has been even a form of resistance against the changes to come. In many countries, the imperative to economize public services is currently prevailing. Under this condition, the employees of that hospital could likely have distrusted any attempt to reduce costs, since this might be the onset of further cuts. Maybe nothing like this affected the intended learning process, because the changes seemed to lead to a win-win situation for everyone, yet it is nothing but extraordinary when resistance and ill-will against the pressure to re-organize and economize one's work or against a normative pedagogical venture arise already beforehand.

Disregarding such impacts of a more general political situation, the article explains the "learning challenge" concerned "a new way of working in which parents and practitioners from different caregiver organisations will collaboratively plan and monitor the child's trajectory of care, taking joint responsibility for its overall progress" (p. 139). Moreover, Engeström emphasizes that "there was no readily available model that would fix the problems" and that "top-down commands and guidelines [were] of little value when the management [did] not know what the content of such directives should be" (pp. 139-140). However, he does not highlight the fact that neither the employees nor the families had influence on how the problem was defined from the beginning. Their perspectives were not present nor articulated when the Laboratory was initiated. Furthermore, the presupposition for what Engeström calls, following Gregory Bateson, "Learning III" (which means that, in the beginning, the solution and the meta-theoretical problem are unclear), was actually not fulfilled: first, because the task was determined from a higher political instance so that the purpose of learning represented a normative goal, 
second, because the researchers already knew about similar "disturbances" in organisational structures and workplaces and introduced an elaborated method to guide the participants to solve the underlying problem. Later the article states more precisely where the actual problem would lie. It explains that, in the past, "care relationships and critical paths were solutions created in response to particular historical sets of contradictions." However, "they do not help in dealing with patients with unclear and multiple diagnoses and they tend to impose their disease-centred world view even on primary care practitioners." Consequently, the prevailing concepts would have caused "great difficulties in representing and guiding horizontal and socio-spatial relations and interactions between care providers located in different institutions, including the patient and his/her family as the most important actor in care" (pp. 143-144).

We do not intend to question here the correctness or the advantage of this interpretation. We rather want to highlight that it represents the official discourse within these institutions but not the different individual perspectives of the practitioners and the families. Their beliefs and views (their interpretive horizons) may have been in agreement with the official line, but we cannot take this for sure. Sometimes people only reproduce what they have been told while thinking in fact quite differently. Therefore, we have to reflect on the quality and validity of verbal data. A well-known problem is that personal beliefs and perspectives are also quite problematic and disturbing for researchers and are therefore neglected, disregarded or even excluded as irrational or non-representative.

In fact, in what follows, we notice that the research group advised the practitioners to accept exactly the perspectives of "horizontal and socio-spatial relations and interactions". This 'insight' therefore seems to be a product of instructions rather than one of (expansive) learning. Furthermore, also the setting in which the Laboratory took place was shaped according to the ideas of the research group, namely the three assumed activity systems: the children's hospital, the primary health care centre, and the child's family.

In the Boundary Crossing Laboratory, the basic constellation of the three activity systems was implemented so that hospital practitioners sat at one side of the room and primary care health centre practitioners sat on another side of the room. The voices of patients' families came from the front of the room, from videotapes made by following patients through their hospital and health centre visits and also from actual parents we invited to join in the sessions. (p. 140)

First of all, one recognizes that room for intersubjectivity (the text includes the terms "multiperspectivity" and "multivoicedness") was given, but it was limited for anticipated reasons: The videotapes of families and patients, as Engeström explains, "made it virtually impossible for the participants to blame the clients for the problems and added greatly to the urgency of the double bind" (p. 140). Later on readers are informed about another conflict, a "tension" between the perspectives of centres and hospitals, but it is not evident how this became apparent during the discussions in the Laboratory: "Health centres in the Helsinki area [were] blaming the university hospital for high costs, while the university hospital criticize[d] health centres for excessive referrals and for not being able to take care of patients who [did] not necessarily need hospital care" (p. 145). Although the delimitation of such a conflict potential can be justified for several good reasons, it would be important to theoretically reflect these strategies to prevent certain dynamics and developments in communication and interaction and to foster others. Thus, despite claims to the contrary, aspects of "learning III"-multiperspectivity, multivoicedness, and expansive learning-are not salient in this research report. 
Since the learners' subjective perspective on the situation is neglected to a certain extent, we shall look closer at the answer to: "Why do they learn-What makes them make the effort?" (p. 141) Without referring to interview data, Engeström suggests that "motivation for risky expansive learning processes associated with major transformations in activity systems is not well explained by mere participation and gradual acquisition of mastery" (pp. 141-142). Instead he consider (according to Bateson) "double binds generated by contradictory demands imposed on the participants" to be the driving force for their learning. Therefore, "we made the participants face and articulate the contradictory demands inherent in their work activity by presenting a series of troublesome patient cases captured on videotape" (p. 142). Here again we notice that not only the initiation for learning came from the "outside," from the research group, but also the introduction of the object of learning (Lerngegenstand). The question whether this raised in fact the motivation of the participants to learn, to solve the problems, and to take risks, however, remains unclear. Engeström articulates contradictory demands to be the motive of learning, but without considering that motivations can be torn apart or go in different directions: The assumed motive to solve contradictions could be mixed with other motives like pleasing the boss to gain or reassure some privileges. This could bring about competitive behavior among team members, or disapproval and resentment, which would affect collective learning unintendedly or even unconsciously. But Engeström does not develop any concepts or representations in relation to his triangular model to reflect such contradictory dimensions. In the following paragraphs that are supposed to clarify, what the practitioners were learning, we can see even more clearly which and why certain dimensions are neglected.

Engeström reports, that "the researchers suggested the term 'knot-working' to capture the idea of the new pattern of activity" (p. 147), which is an expanded one, and in a "ChangeLaboratory"-session the idea of a "care agreement' emerged as the central new concept" (p. 148). The question of how it "emerged" does not seem so important, because in what follows, we can only read the transcript of a discussion about the practicability of such an agreement. While the nurse attempts to see the "care agreement" as a chance for improvement, she also problematizes the additional work for nurses. But exactly this argument against the "care agreement" and the problem of how the increased responsibilities and the work load could be dealt with according to the new division of labor did not become a matter of concern. A data security specialist in fact interrupted the nurse by giving an argument for the newly found "solution." Then, two physicians implicitly denied that there would be any additional work - which might have been correct, but the article does not make it clear. Finally, an information system specialist concluded euphorically: "In my opinion, this is a great system, and as an outsider I say, implement this as soon as possible so that after a sufficient trial period we can duplicate this system elsewhere. This is a great system" (p. 148).

In sum, the excerpt may reveal discursive strategies to suppress the nurse's objections to the "solution" that was partially introduced and favoured by the research group and partially "found" by the practitioners. In this quoted exchange, the nurse, as being in a lower position than the physicians and the specialists, could have been engendered as the only woman in this context, and therefore was unable to present her fears as powerful as it would have been necessary to raise interest for her concerns. All these signs that might indicate some problems of power relations are not discussed nor reflected in the text. Moreover, different interpretation possibilities are not considered or at least not presented. And there is more in the 
specialist's conclusion: Although it may not be a surprise for the technical vocabulary it contains, as it fits with other specific professional expressions of the specialist's work, readers may wonder why this is not problematized as a functionalistic or technicistic misunderstanding of expansive learning, of its nature and its purpose.

At this point, we have to relate these blank spaces in the text to the theoretical framework, because technical terms like "system," "knotworking" and "implementation" are used (pp. 153, 155). Although such a vocabulary is used metaphorically, it nurtures reifications of societal human practice and functionalistic views suggesting that an activity is something that could be taken from one context and be installed in another. This interpretation of an activity system as a unit of analysis neglects a subjective as well as a wider societal plane in which contradictions occur. Accordingly, we continue to investigate where fundamental problems of the concept of activity system lie and proceed by dealing with the notion of contradictions (cf. Langemeyer, 2005b).

\section{What are Contradictions? How is Development Achieved?}

\section{Engeström's Notion of Contradictions and Development}

Drawing on Hegel's discovery of "inner contradictions" as responsible for a movement of consciousness, Engeström adopts this concept and considers them also to be "the source of dynamics and development in human activity" (1987, ch. 2). A contradiction would be a "historically accumulated dynamic tension between opposing forces in an activity system" that "constantly generates disturbances which open up opportunities and call for novel solutions that can lead to transformations in the system" (Engeström, 2005, p. 152). In relation to the "expansive cycle of an activity system," which represents a collective learning process that brings about such transitions, Engeström also highlights the significant role of "internal contradictions as the driving force of change and development" (p. 61). Elsewhere denoted as "systemic", contradictions are interpreted "as tensions within and between the nodes of the activity system aggravated by the asynchronous development of the different elements" (Engeström, 2000, p. 153, our emphasis). Furthermore, "outside influences from neighbouring activity systems [would] constantly enter into the local systems and trigger novel developmental processes" (p. 165). Engeström distinguishes between different types of contradictions:

In the analysis of human activity, four levels or layers of contradictions may be discerned. [...] The primary contradiction of activities in capitalist socio-economic formations lives as the inner conflict between exchange value and use value within each corner of the triangle of activity. The secondary contradictions are those appearing between the corners. [...] The tertiary contradiction appears when representatives of culture $[\ldots]$ introduce the object and motive of a culturally more advanced form of the central activity into the dominant form of the central activity. [...] The quaternary contradictions require that we take into consideration the essential 'neighbour activities' linked with the central activity which is the original object of our study. (Engeström, 1987, chap. 2)

The inner contradiction would manifest itself above all in a "primary contradiction," which derives from that "dual existence" of any tool or instrument in capitalist societies as use- and exchange-value (1987, ch.2). An example for this issue is the work activity of a physician that "includes a tremendous variety of medicaments and drugs" which are "not just useful preparations" but "above all commodities with prices, manufactured for a market, advertised and sold for profit." Accordingly, "every doctor faces this contradiction in his daily decision making" (ibid.) and, furthermore, would have to face "patients as people to heal" as 
well as "sources of income" (Engeström, 2000, p. 152).

"Contradictions" may therefore accumulate within some tool, such as a drug, or between two "elements" of an activity system (e.g. between instruments and objects) since they are interpreted as "tensions within and between the nodes" (see above). According to the thesis that such tensions ("inner contradictions") would lead to a change in the system, contradictions could also appear as "small innovations in practitioners' everyday work actions" (Engeström, 2000, p. 153). But in the particular example of a primary contradiction, we may doubt that it leads to such a desirable change. Political interventions would be necessary to control the market of drugs, but these do not emerge through a physician's central activity "from below" or within its own domain, nor would they be immediately a consequence of "contradictions" between a hospital's and a pharmaceutical company's activity system. The tension between the useand the exchange-value as well as the disturbances of two interacting "activity systems" are misinterpreted as "inner contradictions" and therefore do not serve as an explanation for development. With regard to the capitalist rationality of profit making, we would need a societal concept of contradiction instead of a notion that actually refers to a state of individual consciousness.

These counter-arguments relate to what Peter E. Jones (2003 and 2004) criticizes as a misconception in Engeström's version of CHAT. His theory, Jones argues, fails to realize the analytical difference of use- and exchangevalue, because Marx "was distinguishing [the] process [of concrete work] as a labour process-as 'free, conscious activity'-from 'work under the specific circumstances of capitalism', i.e. from the capitalist production process, the process of valorization." By neglecting the valorization process, the activity system as the "unit of analysis" would ulti- mately reproduce "the "failure to comprehend the labour process as an independent thing and at the same time as an aspect of capitalist production' (Capital, Vol. 3: p. 1000)," because it would "simply enumerate different aspects of the capitalist production process, aspects which are, of course, all present simultaneously [...], but which need to be distinguished as opposites" (Jones, 2003).

In sum, an error in Engeström's theory does not only consist in a lack of comprehending the subjective and intersubjective plane of human activity but also in a missed articulation of societal contradictions. By referring to the concept of an "inner contradiction" (cf. a "double-bind" situation), Engeström tends to psychologize the societal level of human practice. He tends to identify societal, social and individual dimensions (like the motive and the object of activity) instead of comprehending the dialectical interrelation and distinction of societal, social, and psychic processes. Thus, the driving moment for development and change would have to be rethought not only on a subjective but on a societal plane, too.

\section{The Contradictory Comprehension of Human Activity and Development in the CHAT Framework}

A problematic and even contradictory use of the concept of an activity system and its triangular representation thus manifests itself as Engeström tries to capture simultaneously the "germ cell" and the developed "totality" of any activity in general, second, as he seeks to explain the state of an inner contradiction as well as the process of practical development and change but fails to discern sufficiently the subjective and societal plane of practice, and third, as he attempts to grasp the interrelations of a specific activity, but mainly enumerates isolated elements of it and locates them in a fixed system structure. Most problematic about this conception of human activity is that Engeström's approach consequently loses 
the ability to analytically conceive the societal as well as the intra- and inter-individual dimensions of practice dialectically: to grasp it in its specific historical form in which it emerges and in which it is reproduced and transformed. Because the societal structures and relations inherent to human practice are products of historical development-that means, of various actions undertaken by heterogeneous subjects in different societal contexts on a specific societal basis within a certain constellation of power relations-it is necessary to "investigate" and "explore" these scientifically instead of locating them within a predetermined and a-historical system structure. Following Engeström's theory, we can either explain contradictions too generally as an all-contaminating tension between use- and exchange-value, or identify them with local disturbances or partial ruptures that would demand for an "expansive learning" process only. ${ }^{11}$ But how could we find new action possibilities to change practice by means of his approach? We acknowledge that the assembled components of an activity can be helpful for excavating and describing disturbances within institutionally established routines. However, since the elimination of the sources of friction or dysfunctions tends to be Engeström's main concern, a more fundamental critique of the broader context of societal relations is neglected. Given the limits of his notion of activity and contradiction, the dialectics between the levels of individual and societal development and between the levels of particular and general societal processes gets ultimately lost. The process of learning as a process of societal change-even if Engeström considers learn-

11 Not surprisingly, some scholars who neglect the dialectical notion of activity argue in relation to the triangular model that contradictions could be designed into constructive learning environments (Jonassen \& Rohrer-Murphy, 1999) ing in its collective form-becomes overestimated and overdrawn.

Since Engeström's own reports and representations of empirical studies articulate both a limited idea of societal practice and a problematic view on contradictions, we are reminded of the challenges of critical research to understand how societal contradictions are "transverse" and cut "across" the plane of local activities (which the triangular model represents), to investigate how they affect the forms of human relationships, the forms of identities or subjectivities, including the activities of our own research. As we show in our exemplary analyses, Engeström's approach disregards that contradictions tremendously mediate social relations and thereby narrow the scope for development and empowerment. The societal contradictions unfold their effects in a dialectical way and therefore require a dialectical analysis. But several aspects to guide such an analysis are missing in Engeström's theory.

Instead of merely encapsulating systemic interrelations of practice, it would be important to investigate how subjects, by their actions, are confronted with certain societal structures (like power relations). These structures may be determining for individual actions, but since they emerged historically through human activity, they are always determined by individual actions as well. A critical theory therefore needs to proceed dialectically: first by analyzing how societal structures bring about certain actions and how they impair others, how they are internalized by subjects and embodied in their behavior; and second, by excavating —on a social and societal level-action possibilities to intervene and to change those structures that have become problematic for free human development.

Social relationships-like forms of cooperation and modes of participation-come to be reshaped and transformed in the dynamic of struggling with those structures and their underlying power relations that detach the sub- 
jects from taking influence and gaining power to act (cf. Langemeyer, 2005b). Only if we question and criticize our accumulated experience with such problems and conflicts and develop our presently rudimentary knowledge of societal interrelations and contradictions collectively for intervention ("Zusammenhangsund Widerspruchswissen" [Holzkamp, 1988]) in form of a coherent conception of our world (Gramsci, Prison notebook 11, §12, comment 1), do we open up opportunities for tackling and resolving the fundamental contradictions of our society. But we should not expect them to be a "mechanism" of or even an "automatism" for development. Rather we experience that our engagements to change and enhance practice are themselves quite contradictory. In the most challenging entanglements, we therefore need to generate - each time anew-critical perspectives on these societal practices in which we participate, and on our own socialindividual basis to act and to reflect on the problems and conflicts to be resolved. This is why dialectics play beyond its historical influence on CHAT an important role in the practical and theoretical struggles for emancipation and why we should not abandon it to reductionist, functionalist or systemic views.

\section{Acknowledgement}

We thank Seth Chaiklin, Chik Collins, Juha Koivisto, Morten Nissen, and Jussi Silvonen for their critical comments on this article.

\section{References}

Adorno, Th. W. (2005). Minima Moralia. Reflections on a Damaged Life. London: Verso. (First published 1955)

Axel, E., Nissen, M. (1993). Relating Subject and Society in Activity - A Critical Appraisal. In N. Engelsted, M. Hedegaard, B. Karpatschof,
A. Mortensen (eds.), The Societal Subject. Aarhus University Press (pp. 67-79).

Dreier, O. (1999). Personal Trajectories of Participation Across Contexts of Social Practice. Outlines, 1(1), 5-32.

Engeström, Y. (1987). Learning by Expanding: An Activity-Theoretical Approach to Developmental Research. Helsinki: Orienta-Konsultit. (Available at: http://lchc.ucsd.edu/MCA/Paper/ Engestrom/expanding/toc.htm)

Engeström, Y. (1993). Developmental studies of work as a testbench of activity theory: The case of primary care medical practice. In: S. Chaiklin \& J. Lave (Eds.), Understanding practice: Perspectives on activity and context (pp. 64-103). Cambridge, England: Cambridge University Press.

Engeström, Y. (2000). From individual action to collective activity and back: developmental work research as an interventionist methodology. In: P. Luff, J. Hindmarsh, Ch. Heath (eds.). Workplace Studies. Recovering Work Practices and Informing System Design. Cambridge University Press (pp. 150-166).

Engeström, Y. (2001). Expansive Learning at Work: Toward an Activity Theoretical Reconceptualization. Journal of Education and Work, 14 (1), 133-156.

Engeström, Y. (2005). Developmental Work Research. Expanding Activity Theory in Practice. International Cultural-Historical Human Sciences, Vol. 12. Berlin: Lehmanns Media.

Gramsci, A. (1971). Selections from the Prison Notebooks. Edited and translated by Q. Hoare and G.N. Smith. London: Lawrence \& Wishard. (PN)

Haug, W. F. (1996). Dialektik. In: W. F. Haug (ed.), Historisch-kritisches Wörterbuch des Marxismus, Vol. 2 (pp. 657-693), english translation by Peter Thomas (2005): Historical Materialism, 13 (1), pp. 241-256.

Haug, W. F. (2001). Dreizehn Versuche marxistisches Denken zu erneuern. Berlin: Dietz.

Hegel, G.W.F. (1977). Phenomenology of spirit (A. V. Miller, Trans.). Oxford: Oxford University Press. (First published in 1807)

Hegel, G.W.F. (1994). Wissenschaft der Logik. 
Die Lehre vom Begriff (1816). Hamburg: Meiner Philosophische Bibliothek. (English translation available at: http://www.marxists. org/reference/archive/hegel/works/hl/hlconten. htm)

Holzkamp, K. (1988). Praxis. Funktionskritik eines Begriffs. In: Dehler, J., Wetzel, K. (ed.). Zum Verhältnis von Theorie und Praxis in der Psychologie (15-48). Marburg: Verlag Arbeiterbewegung und Gesellschaftswissenschaften.

Holzkamp, K. (1983). Grundlegung der Psychologie. Frankfurt/M.: Campus.

Holzkamp, K. (1993). Lernen: Subjektwissenschaftliche Grundlegung. Frankfurt/M.: Campus.

Horkheimer, M., Adorno, Th. W. (1947/2002). Dialectic of enlightenment: philosophical fragments; edited by Gunzelin Schmid Noerr; translated by Edmund Jephcott. Stanford, Calif.: Stanford University Press.

Il'enkov, E. (1977). Dialectical logic: Essays in its history and theory (Transl. by H. Campbell Creighton). Moscow: Progress.

Il'enkov, E. (1982). Dialectics of the abstract and the concrete in Marx's Capital (Transl. Sergei Kuzyakov). Moskow: Progress.

Jonassen, D., \& Rohrer-Murphy, L. (1999). Activity theory as a framework for designing constructivist learning environments. Educational Technology, Research \& Development, 47, 61-79.

Jones, P. (2003). Activity Theory and the Marxian Legacy. Unpublished paper delivered on 22 October 2003 at the Institute of Education, University of London at the Seminar "Marxism and Education: Renewing Dialogues III, Pedagogy and Culture".

Jones, P. (2004). Ilyenkov and methodological issues in Activity Theory. Unpublished paper presented at the annual "Ilyenkov Readings" conference in Moscow.

Langemeyer, I. (2005a). Kompetenzentwicklung zwischen Selbst- und Fremdbestimmung. Arbeitsprozessintegriertes Lernen in der Fachinformatik. Eine Fallstudie. Münster: Waxmann.

Langemeyer, I. (2005b). Contradictions in Expansive Learning: Towards a Critical Analysis of Self-dependent Forms of Learning in Relation to Contemporary Socio-technological Change. http://www.qualitative-research.net/fqs-texte/ 1-06/1-06-12-e.htm

Leont'ev, A. N. (1978). Activity, consciousness and personality. Englewood Cliffs, NJ: Prentice Hall.

Marx, K. (1970). Marx's Critique of Hegel's Philosophy of Right (1843). Cambridge University Press. Available at: http://www.marxists.org/archive/marx/works/1843/critique-hpr/ index.htm

Marx, K. (1973). Grundrisse. London: Pelican Books.

Marx, K., \& Engels, F. (1969). Werke, Band 3. Berlin: Dietz. English translation available at: http://www.marxists.org/archive/marx/works/ cw/volume35/index.htm

Marx, K., \& Engels, F. (1983). Werke, Band 25: Das Kapital Bd. III. Berlin: Dietz.

Nissen, M., \& Langemeyer, I. (2005). Activity theory. In B. Somekh \& C. Lewin (Eds.), Research methods in the social sciences (pp. 188-196). Newbury Park, CA: Sage.

Ricœur, P. (1990). Soi-même comme un autre. Paris: Seuil.

Silvonen, J. (2005). Some remarks on the Development of Vygotsky's Semiotics. Paper presented at the ISCAR-Congress in Sevilla.

Spinoza, B. de (1989). Ethics. translation by G H R Parkinson, Everyman Classics. (Written 1675, first published in 1677).

Stetsenko, A., Arievitch, I. (2004). Vygotsky's collaborative project: History, politics, and practice in knowledge construction. International Journal of Critical Psychology, 72, 58-80.

Tolman, C. W. (2001). The Origins of Activity as a Category in the Philosophies of Kant, Fichte, Hegel and Marx. In: S. Chaiklin (ed.). The Theory and Practice of Culturalhistorical Psychology. (84-92). Aarhus University Press.

van der Veer, R. (2001). The Idea of Units of Analysis. Vygotsky's Contribution. In: S. Chaiklin (ed.). The Theory and Practice of Cultural-historical Psychology. (93-106). Aarhus University Press.

Vygotsky, L. S. (1978). Mind in society: The development of higher psychological processes. Cambridge, MA: Harvard University Press. 
Vygotsky, L. S. (1987). Thinking and Speech. The collected works of Vygotsky vol. 1: Problems of General Psychology. Edited by R.W. Rieber, A.S. Carton, transl. by N. Minick. New York: Plenum. (First published in 1934)

Vygotsky, L. S. (1997). The collected works of Vygotsky vol. 3-The historical meaning of the crisis in psychology: A methodological investigation. Edited by R.W. Rieber, J. Wollock, transl. by R. van der Veer. New York: Plenum. (First published in 1927) 